\title{
Hanging Out: One of the High Arts of Dialogue
}

\author{
CHARLES SCOTT \\ Simon Fraser University
}

The practice of hanging out represents an example of an informal and yet rigorous practice of dialogue which has educational merits in both formal and informal settings. It can embody the features and capacities of dialogue, and its benefits rest in creating a safe space for interaction, allowing real questions, fostering creativity, and offering an opportunity for learners to explore more deeply their fundamental values and epistemic outlooks. Several dialogical capacities contribute to the possibilities of hanging out as an effective pedagogical practice, and three of them - becoming aware, presence, and confirmation - are briefly detailed. I suggest that hanging out as a pedagogical practice is of value in a world which is ever more complex, connected, diverse, and uncertain.

\begin{abstract}
So in the heart of the desert, on the naked rind of the planet, in an isolation like that of the beginnings of the world, we built a village of men. Sitting in the flickering light of the candles on this kerchief of sand, on this village square, we waited in the night. We were waiting for the rescuing dawn-or for the Moors. Something, I know not what, lent this night a savor of Christmas. We told stories, we joked, we sang songs. In the air there was that slight fever that reigns over a gaily prepared feast. And yet we were infinitely poor. Wind, sand, and stars. The austerity of Trappists. But on this badly lighted cloth, a handful of men who possessed nothing in the world but their memories were sharing invisible riches. -Antoine de Saint Exupéry, Wind, Sand and Stars
\end{abstract}

\section{Introduction}

Anyone can hang out. It is easy, fun, almost effortless-which makes it an attractive pedagogical practice. And yet hanging out can embody the most rigorous dialogical disciplines-which also makes it an attractive pedagogical approach. When hanging out, we are attentive, open and receptive, alive to the moment, keenly interested in the others and the subject at hand, even if all of this occurs in a "laidback," seemingly effortless fashion. The casual nature of hanging out hides, as it were, the reality that it can embody these disciplines. Dialogue itself can be about just hanging out, and my own experiences have shown me the value of hanging out as a means of engaging in dialogue. I suggest here that hanging out represents one of the highest arts of dialogue, one that should be encouraged in our educational and organizational efforts. Hanging out as a teaching method is, I think, applicable both to more traditional educational settings and those less traditional, involving, for example, adults in organizational learning (see, for example, Senge, 2006; Scharmer, 2007). Patrick Hill (2004) points to the possibilities of hanging out:

To just hang out together with no pre-chosen agenda. Some of my students have nearly convinced me that the willingness to make time for hanging out is both the pre-requisite for genuine dialogue and perhaps as well (surprisingly) its ultimate goal. Some academics who

(C) Copyright 2009. The author, Charles Scott, assigns to the SFU Educational Review the right of first publication and educational and non-profit institutions a non-exclusive license to use this document for personal use and in courses of instruction provided that the article is used in full and this copyright statement is reproduced. Any other usage is probibited without the express permission of the author. 
recognize its importance frequently undermine the admission by setting a limit on hanging-out time; or by buying into the great American hoax of "quality time." (Hill, 2004)

In this examination of hanging out as educational pedagogy and its possible benefits, I will first give a brief definition and description of dialogue, and follow that with a description of hanging out. I will explain why it is valuable and how the disciplines of dialogue make it possible. The seemingly effortless nature of hanging out is what makes it appealing, and the effortful disciplines of dialogue, paradoxically enough, are what make it possible. ${ }^{1}$ I will also critically examine some of the challenges of hanging out which emerge out of the very reasons why we might want to allow it as a possibility. I am focusing here on some of the subjective and intersubjective conditions which make educational hanging out possible, but there are a number of physical and sociocultural conditions which also contribute to its possibility. Both Jürgen Habermas (1979) and Ken Wilber (2001) have noted the significance of subjective, intersubjective, and objective dimensions to human behaviour, and I am mindful that a number of other variables are worthy of consideration; their consideration will only add to the conversation around the viability of hanging out as a pedagogical practice.

\section{Dialogue}

Dialogue as a pedagogical approach has been suggested by a number of educational scholars (see, for example: Banathy \& Jenlink, 2005; Bingham \& Sidorkin, 2004; Buber, 1947/2002, 1958/2000, 1965a; Burbules, 1993; Burbules \& Rice, 1991, 1992; Freire, 2006; Garrison, 2004; Jenlink \& Banathy, 2008; Laverty, 2007). Scholars and educators point out that dialogue can serve as an effective pedagogical means, allowing educators to reach any number of goals. Dialogue is sometimes defined as a disciplined form of verbal and nonverbal communication aimed at achieving greater mutual understanding, whatever other goals it may have; it is usually, although not always, conceived as a form of conversation, and is often distinguished from discussion and debate (Isaacs, 1999; Yankelovich, 1999). The late physicist David Bohm became convinced of the importance of dialogue as a result of his work in quantum physics; he described dialogue as follows:

"Dialogue" derives from the Greek word dialogos. Logos means "the word," or ... the "meaning of the word." And dia means "through."... Dialogue can be among any number of people, not just two... The picture or image that this derivation suggests is of a stream of meaning flowing among and between us. This will make possible a flow of meaning ... out of which may emerge some new understanding. (Bohm, 1996, p. 6-7)

Although Bohm's work in dialogue centered around organizing disciplined conversations among several people in what became known as "Bohmian dialogue," his definition points us, however indirectly, to the ontological orientation to dialogue that Martin Buber took. For Buber, dialogue, while it certainly included conversation, was not confined to or defined by it; moreover, it was not something one did inasmuch as it was something one lived as a matter of being. He argues that dialogue can indeed have its "distinctive life" in the signs of outward communication, but that "in its highest moments dialogue reaches out even beyond these boundaries" (Buber 1947/2002, p. 5). Paradoxically, dialogue is a matter of "unreserved communication," sometimes borne in silence, in which one is fully there for the other. Then "the word of dialogue has happened sacramentally" (Buber, 1947/2002, p. 5). Again, paradoxically, while Buber suggests no more knowing is needed or has happened, and that even

\footnotetext{
${ }^{1}$ This contrast between effort and effortless might remind some readers of the Daoist concept of wu wei: action without action, or effortless action. See Cohen \& Bai (2007), Cohen (2008), and Yunchuan (1996) regarding the applications of wu wei to education.
} 
if no outward sign of communication has taken place, he admits that the individual "does something": "he releases in himself a reserve over which only he himself has power" (p. 4), and a transformative bond is developed.

Dialogue is established by individuals being "turned to one another" (p. 9) in which one becomes aware of the other and confirms the other's ontological status: "In this way, that out of the incomprehensibility of what lies to hand this one person steps forth and becomes a presence" (p. 25). One of the significant outcomes of such an ontological conception of dialogue is that it opens the door to a number of capacities which include but also extend beyond the capacities of purely verbal communication. Various writers have listed what are known as the capacities or disciplines of dialogue (see, for example, Bohm, 1996; Burbules \& Rice, 1992; Isaacs, 1999; Yankelovich, 1999). Classically, they include such capacities as listening, patience, making the effort to suspend one's assumptions and judgments, respect, empathy, a spirit of inquiry, a spirit of openness and vulnerability, and a spirit of advocacy. ${ }^{2}$ I will return to a brief examination of some of these capacities later in the paper.

\section{A Brief Sketch of Hanging Out}

I am using the phrase "hanging out" to describe what are essentially informal occasions where two or more people are communicating casually. For the purposes of this paper, I will more or less confine the discussion to interactions between people. However, dialogue is not-at least, not in a Buberian sense-confined to interactions of people with only other people. Dialogue can occur between humans and animals and even between humans and non-sentient beings. ${ }^{3}$ The occasion may be planned, or not; the topic of the conversation may be set in advance, or not. The participants do not feel forced or coerced into having the conversation develop or unfold in a certain fashion; it will flow as it will, and there is no sense of the burden of having to produce a certain outcome or result. They also feel comfortable, or develop at least a degree of comfort, with each other; there is a sense of being able to speak freely, even if this encounter is not necessarily an easy one-being comfortable can and may need to include comfort with agonistics. There is a sense of respect for the others, whether intentionally brought into or developed during the conversation. There is also a sense of equality among participants - or at least recognition of otherness—and participants do not feel status impedes their ability to speak as they wish, although there is recognition that status may in fact be an issue. Not all of these are absolute requirements of what we might call hanging out; rather, they can be seen as its indicators.

The outer conditions-the physical setting and circumstances-are not particularly significant for this examination of hanging out, as noted previously, although they can play a role: some physical environments (and, indeed, sociocultural environments) can be conducive to hanging out. Rather, it is the inner conditions that are present or which emerge during the conversation that are of significance, and they are casual, loose, unrestricted. Actually, the casual elements that define hanging out also help define what I think dialogue can reflect and manifest. Hanging out can represent a form of dialogue beneficial to educators. ${ }^{4}$

\footnotetext{
2 One reviewer asks whether these are realistic possibilities. It's a good question. Without going into detail: I think they are. However, it's worth saying that these could be seen as goals worth striving for, even if they are not fully manifested.

${ }^{3}$ For the classic Buberian reference here, see Buber's description, near the beginning of $I$ and Thou, of his encounter with a tree in which he becomes "bound up in relation to it." He writes that the tree is "bodied over against me has to do with me, as I with it," that the relation is mutual (Buber 1958/2000, p. 23). Thus, one could hang out with a tree.

${ }^{4}$ It's interesting to contrast the somewhat rigorous nature of the disciplines of dialogue with the informal nature of hanging out. While one might think that they are mutually exclusive, it is the sense of respect for and
} 
Princeton University's WordNet defines "hang out" as follows: "Spend one's free time in; also, loiter, pass time idly. For example, They hung out around the pool parlor, or They spent the evening just hanging out [Slang; mid-1900s]" (Dictionary.com, nd). Merriam-Webster defines "hanging around" as an intransitive verb, to wit: " 1 : to pass time or stay aimlessly : loiter idly 2 : to spend one's time in company transitive senses : to pass time or stay aimlessly in or at <hung around the house all day>" (Merriam-Webster, nd).

It's interesting to note that the definitions both mention the notion of time idly or aimlessly spent. On the contrary, I am suggesting that hanging out is not only productive (of deepened relationships) but is also active. But the definitions help lend a flavour to what the concept of hanging out: a freely chosen, relaxed occasion where all participants willingly contribute to whatever degree they wish in whatever ways they wish; just spending time together is, in and of itself, an important feature. ${ }^{5}$ Willingness and the attitudes, practices, and conditions which make it possible are all that are required. That sense of just hanging out together occurs everywhere, between all sorts of people, usually with small groups. And with the slightest of nudgings, we can create opportunities for such informal, relaxed get-togethers. Daniel Yankelovich, author of The Magic of Dialogue (1999), mentions that he has regularly found that the best, most dynamic and productive dialogues occur, not in formal meeting or board rooms, but in the walks in the woods or around the block, or while lounging around hallways or dining rooms between formal settings. Yankelovich (2004) now makes it a point to allow such informal interactions whenever possible.

\section{Why Hang Out?}

As a teacher, you have a curriculum that needs to be taught. Although you see that there is some value and a need for some interaction between you and the students, you may feel spending time in conversation that might wander and get off-track is something you cannot afford. As a manager, you have an organization to run, or at least a group within an organization to manage. Although you support open, honest, and two-way communication, you may feel allowing casual conversations in the midst of what might be considered formal, important, or professional communication efforts just wastes time and isn't productive. Both of these sentiments are understandable but may be shortsighted. There are very good reasons to encourage hanging out to be a part of educational and organizational efforts. There are a number of benefits to individuals and groups that hanging out can offer, which I now consider. I note here (and the point will be re-visited later) that these benefits themselves constitute practices which contribute to the dialogical ethos of hanging out. For example, creating a sense of safety is both a fruit of and practice contributing to hanging out. This fluidity between what contributes to and flows out of the dialogical engagement constitutes part of the paradoxical nature of dialogue itself.

\section{Creating a Sense of Safety That Allows Openness}

The first benefit is the sense of safety that hanging out conveys. The lack of formal guidelines or goals allows those involved to feel more at ease in saying what might be on their minds. In such a casual atmosphere, it is likely that a sense of respect between people can develop. When people feel they and

confirmation of the other underlying the disciplines of dialogue that makes the informality — and the rigors—of hanging out a possibility.

${ }^{5}$ One reviewer of this paper notes: “. . . in my teaching career, I often feel that there are far too few opportunities for "hanging out." I think this is significant. If teachers feel that hanging out is a worthy educative means, and if they also feel they don't have the opportunities to do so, might we need to consider both the value of hanging out and ways we might pedagogically incorporate it? 
their views are respected (especially when those views differ), they are more likely to participate in talking with others. Even in the midst of disagreement, there can be a deep sense of caring. Of course, people will bring respect and caring to the conversation, but the informal nature of hanging out itself helps develop, nourish, and sustain a sense of safety, and all that flows from it.

In his chapter on education of character in Between Man and Man, Buber (1947/2002) points out that a teacher's spontaneity is necessary for the teacher to be able to effect the "whole being" of the student, and that "unscripted" opportunities allow this spontaneity to arise. He adds that there is but one opportunity to reach the student: through winning her confidence. This allows the student to develop the "liberating insight" into "the truth of human existence" (pp. 125-126). He adds:

When the pupil's confidence has been won, his resistance against being educated gives way to a singular happening: he accepts the educator as a person. He feels he can trust this man, that this man is not making a business out of him, but is taking part in his life, accepting him before desiring to influence him. And so he learns to ask. (Buber, 1947/2002, p. 126)

Buber adds that the teacher may be approached by a student who is defiant but who comes with "trembling hands visibly opened up and fired by a daring hope," approaching possibly with a deeply personal matter. By meeting with, being with the student, the teacher can instill confidence in the student; it is the meeting itself which Buber argues is significant and "educationally fruitful"; it "opens a way to the education of character," and the confidence instilled can allow a "bursting of the bonds which imprison an unquiet heart" (p. 127). Those who create opportunities for hanging out-whether in classrooms or in corporate settings - through their involvement can model respect and a sense of caring for others and their views. Through their verbal and nonverbal communication, they can help create an atmosphere that feels safe and where people feel they can say what is on their minds, and perhaps explore more deeply the values which underlie their views. Those who hang out together have an opportunity to get to know one another far better than they might ordinarily. One is likely to feel less obliged to put on some kind of false front, as in a more formal setting. Indeed, when hanging out together, participants adopt, at least temporarily, a greater sense of recognition or equality: they are more inclined to see what is common between themselves; at the same time, such a meeting might afford a greater and more respectful appreciation of difference, of the unique, and of the ever present otherness - of all the ways the participants are not equal, not the same, and do not share the same ideas or worldviews.

Out of all this, a sense of safety and intimacy can develop. Indeed, hanging out can allow the sorts of intimacies E. E. Cummings expresses in his poem, somewhere $i$ have never traveled, gladly beyond:

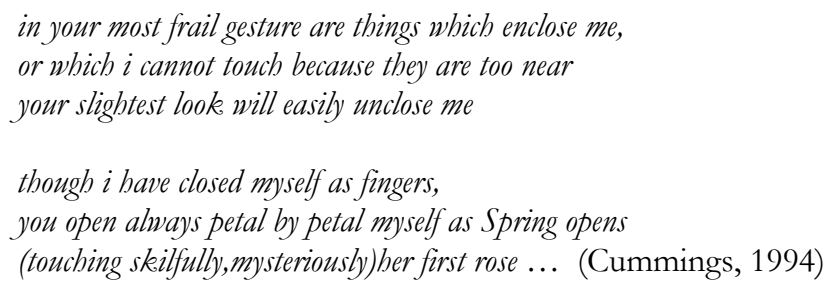

The personal and epistemological intimacy is a point to which I will return later in the section "Getting to Deep." But hanging out can allow this sense of safety to emerge, partially through the careful listening of participants. I once had an experience about how hanging out created a sense of safety and allowed the sharing of deeper values which deepened a relationship.

During a job as a municipal gardener, I worked alongside Mark, who spent much of his time being sure we all knew that he was a great guy, that he was tough (and had been kicked out of the Canadian Armed Forces because he was "too tough"), that he could drink anyone under the table, and that he was a real Casanova; he seemed to epitomize braggadocio. One day, we were paired together to 
work in a park by ourselves. As we worked, we started talking. Apparently freed from the need to maintain an image, Mark began asking about my life. Seeing my willingness to open up about what was important to me, and finding that my life had some unconventional elements to it, he gradually began to open up about his own life, talking about events in his life that revealed deeply held values (this involved some back-and-forth conversation that allowed Mark to develop a sense that he could gradually reveal more about himself). A far more sensitive and thoughtful person emerged-more correctly, two more sensitive and thoughtful people emerged-and we found commonalities that otherwise would have never revealed themselves. The significance was that our relationship was now forever changed: we had both learned more about each other, including some intimate details, and how we worked together in the future was indeed changed by this one occurrence. This is similar to Charles Bingham's (2004) story of a student receiving empathic understanding from an English professor who listens to and empathizes with her story of her grandmother's recent death; in effect, she just hangs out with Julie. Another professor fails to show any empathy and loses both Julie's respect and her willingness to work hard for that professor. Once again, the relationships have been altered by the presence or lack of a sense of hanging out.

Donald Winnicott observes: "The potential space between ... individual and society or the world, depends on experience which leads to trust. It can be looked upon as sacred to the individual in that it is here that the individual experiences creative living" (Winnicott, 1971, p. 139). Creating a climate of safety and trust is a matter both of being (who we are, and the qualities we bring to our conversations) and doing (what we do in the conversation). There are verbal and nonverbal actions we can perform to make others feel safe: a simple gesture of empathy or respectful listening. The simple intention to create a safe atmosphere is a factor.

Having said this, it is important to point out that we cannot guarantee safety. Hanging out may well surface issues which are troubling or painful. Indeed, as William Isaacs (1999) points out, the feelings of safety can open the possibility of surfacing tension, disagreements, and opposition. Circumstances may be that some feel their voices are privileged while others feel just the opposite.

\section{Allowing True Questions}

As Hans-Georg Gadamer (2004) points out in his discussion of the hermeneutic priority of the question in Truth and Method, the question is often more difficult and challenging than any answer openness to questioning and to questions characterizes what he calls hermeneutical consciousness. This openness also allows us to explore the "knowledge of not knowing," the Socratic docta ignoratia. To be able to ask means that one wants to know, and, further, to admit that one knows one does not know. We can see, for example, poor Meno lovingly but yet decisively wrapped into a pretzel of perplexity by Socrates' repeated challenges to the validity of his questions and to the concerns that arise out of a simple reply to what is actually a profound question. In the end, Socrates praises the joint questioning of how virtue arises as, in itself, a noble venture. A question, asserts Gadamer, "breaks open the being of an object." The epistemological value lies in considering new things. As Gadamer notes (2004), "Knowledge always means, precisely, considering opposites. Its superiority over preconceived opinion consists in the fact that it is able to conceive of possibilities as possibilities" (p. 365).

We can imagine that hanging out can allow the asking of genuine, sincere, difficult, and perhaps complex questions: the true questions that allow us to seek answers, and that allow us to develop our thinking and relationships. Indeed, Gadamer goes out of his way to point out that true questions require the kinds of openness hanging out can afford. ${ }^{6}$ The casual, respectful atmosphere can allow

\footnotetext{
${ }^{6}$ Gadamer also points to the role of "passion" in questioning. The role of eros in developing the kinds of dialogical interactions in hanging out is beyond the scope of this paper. Suffice it to say that eros plays a significant role in teaching and in fostering dialogue, which is acknowledged by Buber (1947/2002), Mary Doll (1995); James Garrison (2004), Susan Griffin (1995), Tim Lilburn (1999), Audre Lorde (2007), and Celeste
} 
people to feel they can ask questions they otherwise might hesitate in asking. Although the atmosphere is in some senses casual, this does not mean it lacks intensity or even rigor. As Gadamer points out, dialectic consists not in arguing but in the kinds of questioning that will allow real thinking to occur. And not only real thinking, but also real feeling-an increased awareness of one's emotional responses. Not only are genuine questions-which may be risky or unsettling-beneficial for us as individuals, they are also beneficial for our organizations and social order. We all know of organizations, for example, that set up "skunk works" opportunities to ask the difficult, not-considered, challenging, risky, or off-the-wall questions that otherwise may never be asked. Out of such explorations, useful and creative solutions have emerged, which brings us to the consideration of creativity.

\title{
Allowing Creative Exploration and Expression
}

And providing opportunities for creative exploration is another benefit. As Barbara Stengel (2004) makes clear, learning takes places "in the presence of relation," and she writes about how the leisurely nature of her interactions with her daughter made creative learning possible as her daughter became engaged with reading: "I opened the door to the world of books that is my leisure; Emily entered" (Stengel, 2004, p. 151). What was noteworthy was that Emily learned far more as a result of the informal "hanging out" relation with her mother than she did from her more formal relationship with her teacher. Education, writes Stengel, is "response-able." Informal hanging out offers us chances for creativity and spontaneity: to consider the seemingly outrageous, the possibly unimaginable, and the deliciously absurd. Within the bounds of common decency, there are no bounds to what might be considered and talked about. Hanging out also offers a chance for the conversations to weave and flow in whatever directions they might. All too often, I have noticed in formal dialogues the temptation to control and steer the conversation acted out at the cost of losing the creative and spontaneous flow. There is a fear of going into the unknown, curricularly and pedagogically. Jelaluddin Rumi says something about spontaneity:

\author{
Who Says Words With My Mouth? \\ This poetry. I never know what I'm going to say. \\ I don't plan it. \\ When I'm outside the saying of $i$, \\ I get very quiet and rarely speak at all. (Barks, Moyne, \& Rumi, 1997, p.2)
}

Ted Aoki (2005) writes about the "situational interpretive inquiry" orientation to curriculum, which is both phenomenological, allowing an inner exploration of ideas, values and feelings, and hermeneutic, allowing mutual, dialogical explorations of these themes. Such a curricular orientation allows exploration of the "deep structures of meaning" as well as the attempts to "provide explanations of an interpretive kind" (p. 104). Praxis then becomes "situational," and knowing "arises not from inward speculation but from intentional engagement with, and experience of, lived reality" (p. 120). In such an approach, competence is determined, as the etymological roots of the word would suggest, through a

Snowber (1999, 2005). I would suggest that eros plays a significant, decisive role in the emergence of dialogue, both as a practice and as a way of life. Relatedly, it is fascinating to observe the role of eros in the lives of such advocates of dialogue such as Buber, Gadamer, and Habermas.

7 The term "skunk works" is used in business or engineering to denote sub-groups in an organization which are given and operate with a high degree of autonomy; they are free to pursue creative or advanced projects which may lie outside the set mandates of the organization. The term originated with Lockheed when it was tasked with developing a new fighter aircraft just before the onset of WWII. 
mutual seeking and venturing forth. ${ }^{8}$ The move is to "dwell in the earthy place where we experience daily life with our colleagues and students, and begin our search for the 'isness' of teaching, for the being of teaching" (p. 190), a place where "care dwells, a place of ingathering and belonging." This "lived curriculum" differs distinctly from what Aoki terms the "curriculum-as-plan" in that the former is emergent, and to some degree unknowable; in hanging out, we unconsciously assume we do not know what is to come, but we are, to varying degrees, open to the possibilities. There, knowledge and identity are not necessarily things already present and determined, but are rather in the process of emerging, "in the throes of being constituted as we live in place of difference" (p. 205). It is a space, existing on the narrow ridge between modernity and postmodernity, which allows "humanly embodied narratives to dwell contrapuntally with metanarratives" (p. 209). Richard Bernstein (1991), appropriating the concept from Theodor Adorno, argues that such a space represents a kraftfeld, a force field in which there is a relational interplay of attractions and aversions. Such a space represents a possibly creative engagement between worldviews which might differ radically.

Hanging out can allow the emergence of that state of flow that Mihály Csikszentmihalyi (1991) refers to in his book Flow: The Psychology of Optimal Experience. He mentions that flow often appears in informal settings: sports, games, arts, hobbies. At the same time, such experiences are often the result of pushing oneself to one's limits; they do not emerge from passive, relaxing times. These physical, intellectual, emotional, and spiritual efforts constitute the rigors of hanging out: while it can be relaxed and seemingly passive in one sense, it can also be intense. But flow remains a state in which "people are so involved in an activity that nothing else seems to matter; the experience itself is so enjoyable that people will do it even at great cost, for the sheer sake of doing it" (1991, p. 4).

That state of flow or creativity allows for another significant emergence: the ability to see or make connections between concepts, ideas, forces, events, and people: a systemic and ecological approach to thinking, feeling, and intuition. This is significant insofar as we increasingly live in a connected world, where neither people nor actions are isolated or without their effects on others. We need to be able to see not only individuals but groups as wholes, and how those individuals and groups of individuals influence one another. Furthermore, in an increasingly complex world, it's necessary to risk new ways of thinking and feeling, and to experiment with and validate our intuitions. This combined sense of creative, chaotic, and systemically-ecological thinking is a significant capacity of dialogue, one that can both be brought to occasions where we hang out and emerge from them. From Rumi:

There's a strange frenzy in my head,

of birds flying,

each particle circulating on its own.

is the one I love everywhere? (Barks, Moyne, \& Rumi, 1995, p. 4)

And again, with an emphasis on awareness of relations:

Special Plates

Notice how each particle moves.

Notice how everyone has just arrived bere

from a journey.

Notice how each wants a different food.

Notice how the stars vanish as the sun comes up,

and how all streams stream toward the ocean.

Look at the chefs preparing special plates

\footnotetext{
${ }^{8}$ And Aoki argues that such venturing forth can include a critical component, grounded in a moral stance of liberation from oppression, adding that critical competence manifests in all the ways we choose to oppose inhumanity, be they through the arts or everyday language.
} 


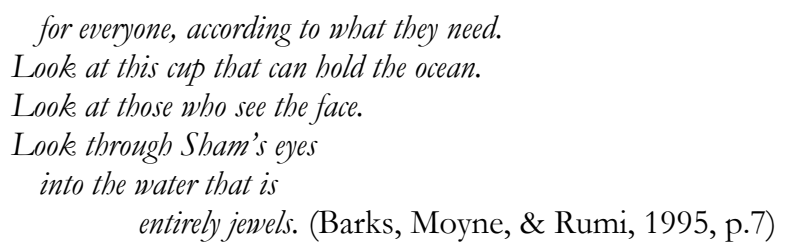

Out of the understanding developed through such noticing can come the second significant feature: an ability to create effective communications which allows a group to shift strategy and response to changing conditions, as required; there is the response of poiesis, what Robert Bringhurst (2002) refers to as "a music we learn to see, to feel, to hear, to smell, and then to think, and then to answer" (p. 163). Moreover, as Barbara Thayer-Bacon (2003) argues in her work on relational epistemology, not only do educational settings need to provide a connected, multidisciplinary curriculum, they must also provide opportunities for students to develop close, personal, and caring relationships with teachers and each other where learners can realize that they are embedded in interactive sociocultural systems that themselves are embedded in historical contexts. Thayer-Bacon (2003) highlights "We now can have a greater understanding of our own situatedness for we can compare ourselves to others. . . These contrasts [with others] also expose us to other possibilities and differences and help to stimulate our ideas of what is possible" (pp. 251-252).

She adds that our overstructured classrooms do not allow the kinds of "off-task" behaviorsuch as hanging out - that can lead to that delightful chaos that Maria Montessori, for example, so cherished. Stacey Reeder has applied such principles to the teaching of mathematics, and she argues that pedagogical interactions - even in a math class! - can give way from "linear, lock-step approaches" to those in which there is an "ebb and flow [of] dynamical interactions of a conversation" (2005, p. 248). Hanging out can be a wonderfully chaotic experience where conversations weave in ways that might be initially inconceivable. New and perhaps even radical ideas can emerge out of the relaxed atmosphere. Donna Trueit (2005) states that such conversation "plays with meaning and relations, transgresses, narrates and questions, and in so doing begins to recognize and then challenge the bounds of certainty" (p.78). William Doll (2005) suggests that the ethos of chaotic learning can embody humane struggle that is educationally deep, lovely, and intellectually stimulating, allied with the pragmatist ideas of Charles Peirce, John Dewey, and William James. Such learning, he suggests, is ongoing, recursive and emergent. ${ }^{9}$

\section{Getting to Deep}

As mentioned previously, hanging out has the potential of allowing the conversations to go to deeper levels of understanding - the levels of meaning and being. It is to these levels I think so much of conversation - in whatever forms - needs to go. Buber talks about "genuine" conversations: "not those so-called fictitious conversations where none regarded and addressed his partner in reality, but genuine dialogues, speech from certainty to certainty, but also from one open-hearted person to another openhearted person" (Buber, 1947/2002, pp. 7-8). Successful dialogues, which result in new understandings or outcomes, and actions useful to the participants, are those which make some contact with these deeper levels of meaning. Hanging out can allow such successful dialogue to happen. But hanging out takes time as unfolding and uncovering levels of meaning, petal by petal, touch by touch, is a timeconsuming task and people must also sense they can safely share their innermost convictions and feelings without being unduly criticized or marginalized. The sharing becomes an essential element: "Each must expose himself wholly, in a real way, in his humanly unavoidable partiality, and thereby experience himself in a real way as limited by the other, so that the two suffer together the destiny of

${ }^{9}$ Doll's remarks may remind readers of and indeed emerge out of William Pinar's curricular orientations. 
our conditioned nature and meet one another in it" (Buber, 1947/2002, p. 7). Peter Garrett, working with David Bohm's approach to dialogue in maximum security prisons, found that where there was a willingness to ask profound questions, and to go out on the ridge; even in the midst of disagreement, there could be civility and genuine community: "Inquiring deeply enough to reach the original impulse will always reveal wholesomeness. This provides the confidence to enter the loudest confrontation and the darkest territory without fear that it will get forever worse" (Garrett, cited in Isaacs, 1999, p. 121). While we might be hesitant in accepting that we would always get to "wholesomeness," we might be willing to risk the efforts in trying to do so.

\section{Getting to Deep: The Rigors of Dialogical Hanging Out}

Dialogical hanging out is rigorous. It embodies a set of rigors which help it serve as a viable vehicle for learning, and as a means of getting to deep. These are what I call the capacities of dialogue, a collection of intellectual, affective, and spiritual capacities which develop dialogue as an ontological orientation. ${ }^{10}$ These capacities are what make possible the asking of true questions, the creation of safe spaces, the creative explorations, and the deep, meaningful engagements. They include becoming aware (listening), being present, confirmation of the other (respect), mindful suspension of one's assumptions and ideas for examination by oneself and others, openness and receptivity (what Buber calls a willingness to adopt the "holy insecurity"), what Buber calls "making [the other] present" or "inclusion" (empathy), advocacy or voicing, systemic or ecological thinking, the skills of (Habermasian) communicative action, and the abilities to comprehend dualities and paradox. Here, I will only focus on the first three, and then only briefly.

\section{Becoming Aware}

Buber's (1947/2002) entire ontological conception of dialogue rests in what he calls the "basic movement" of a responsive, ontological turning toward the other. That responsive turning is itself made possible through the process of "becoming aware." Awareness begins its development with and prepares the ground for "meeting," and with our being receptive enough to perceive that people and indeed all sentient and non-sentient beings "say something": when we feel that the person or thing or event before us presents meaning, addresses us, reaches out to contact us. That which is calling or addressing may be out of my awareness and, indeed, may emerge partially from within me. But still, in that present situation, I feel addressed and so a relationship is forged. Buber adds that "Nothing can refuse to be the vessel for the Word. ${ }^{11}$ The limits of the possibility of dialogue are the limits of awareness" (Buber, 1947/2002, p. 10).

\footnotetext{
10 They are akin to what Burbules \& Rice (1992) call "communicative virtues," a constellation of intellectual and affective dispositions which enable communication, and which they list as including patience, tolerance for alternative points of view, respect for differences, the willingness and ability to listen attentively, openness in giving and receiving criticism, and honest, sincere self-expression. I would stress that the capacities I outline also have spiritual and existential dimensions, can be developed through an integral approach (Wilber, 2001), and contribute to dialogue as an ontological orientation, that being the essence of Buber's philosophy of dialogue. 11 The Word is, of course, Logos. Logos in turn as "word," "speech," or "reason," or "meaning," or in the Johannine verses of the New Testament as the divine "Word" (Buber is referring to them all). Martin Heidegger (1975), John Sallis (1986), and Gemma Fiumara (1990) point to the Greek sense of logos of "bringing things to lie together, collecting them, gathering them together," referring to the earlier Greek root legein. In one essence at least, logos is about creating and distilling meaning; and that it should be done together, in the Buberian "sphere of between" makes all the more sense.
} 
Carol Hwoschinsky (2002) outlines three levels of listening that can help develop openness. At the first level, we're listening simply to facts and reports of what is going on. At the second level, we're listening and attentive to the feelings behind the reportings of what's happening. These are more significant, obviously, but one can see that a sense of respect, caring, and safety is needed before many will begin to divulge their feelings. The willingness to be vulnerable can play a role in allowing participants to reach this second level. In addition to listening for the feelings, if one is willing to risk being vulnerable, to open up about one's own deeply held beliefs and values, it is more likely that others will come out from behind any walls of reservation. Even more significant is getting to the third level of listening. This is the level Hwoschinsky calls essence or being. This is where I become aware of and attentive to the most profound and elemental values the other person expresses and personifies in his or her life. This requires a skilful and mysterious touching response, requiring perhaps the slightest look, the careful opening petal by petal into the heart of a person's life.

\section{Presence}

Buber (1947/2002) points to the significance of full presence, of being fully engaged in the encounter. Out of a personal experience of his, when a young man came to him in need, he writes: "He had come to me, he had come in this hour. What do we expect when we are in despair and yet go to a man? Surely a presence by means of which we are told that nevertheless there is meaning" (p. 16). He goes on to add the "mysteries" of life dwell in each moment, here "everything happens as it happens," that each hour claims responsibility, and ... in the claim I am claimed and may respond in responsibility ..." (p. 16). Regardless of the relational situation, he argues that "you with this your mortal bit of life are referred to" and life beckons for your presence. ${ }^{12}$ On another occasion (a classic Buberian reference), when Buber as a young child was stroking a horse, he was fully immersed in the encounter until a moment when he became focused on his own hand and the enjoyment he was experiencing-reflexive of his own experience-and he was no longer fully present with the horse. Buber refers to the basic movement of dialogue as turning to the other, and that turning, made possible by becoming aware, is done with full presence. Moreover, one is required to "take a stand" not only in relationality, but as one representing an episteme. Being fully present allows one then the possibility of "accepting with his essential being another person in his particularity" (p. 27).

\section{Confirmation-Respect}

It is one's awareness of and receptivity to the other which put one into relation with the other; out of that awareness and openness come the response and the attendant confirmation of the other: ". . . out of the incomprehensibility of what lies to hand this one person steps forth and becomes a presence" (Buber, 1947/2002, p. 25). If we are to consider another person, another epistemic position, it stands to reason that we should be willing to grant the person a significant degree of respect. Confirmation of and respect for the person-person qua person-allows a foray into the careful consideration of the person's life and epistemic position. Respect can involve the act to which the Latin roots of the word point: to look again. Respect does not have to mean there will be agreement or consensus; respect for difference is just as important. At its limits, respect opens up the possibility of an I-Thou relationship.

\footnotetext{
12 There is an additional metaphysical dimension to Buber's desire for presence: presence in and through the world, for both humanity and God. In his mature thought, he was a panentheistic nondualist who saw no separation between the world and God; he rejected both the concept of a wholly transcendental God and Manichean dualisms. In his reply to Søren Kierkegaard, who had renounced his love for his fiancé in order to be the "Single One" who determinedly sought God, Buber wrote: "Creation is not a hurdle on the road to God, it is the road itself" (Buber, 1947/2002, p. 60).
} 
Only he who himself turns to the other human being and opens himself to him receives the world in him. Only the being whose otherness, accepted by my being, lives and faces me in the whole compression of existence, brings the radiance of eternity to me. Only when two say to one another with all that they are, "it is Thou," is the indwelling of the Present Being between them. (Buber, 1947/2002, p. 35)

These and the other capacities of dialogue are the rigors which make hanging out an educational possibility. They can be developed through practice that is regular, focused, and persistent, and are best developed through a practice which integrates the somatic, intellectual, affective, spiritual and existential dimensions of one's life, a practice which occurs in and through the contexts of one's relationships with others and with surrounding physical, sociocultural, and historical ecologies.

\section{Critical Concerns}

As mentioned, hanging out is not always necessarily going to be pleasant or easy. Megan Boler (2004) has edited a collection of essays touching on the considerable difficulties of dialogue in situations where voices do not carry equal weight, where some may, even despite best intentions, dominate, while others are marginalized or represent marginalization. While the ethos of hanging out can represent an opportunity for voices to be heard and recognized, there might also be people present who feel they are not privileged to speak or be heard. Alison Jones (2004), for example, correctly points out that the desire for dialogue in classrooms may simply serve what are ultimately colonializing efforts, however subconscious and unintentional these are; hanging out can potentially represent colonization. Further, attempts to privilege the voices of the marginalized might be done at the expense of those who might oppose them, creating an additional challenge (Boler's response is that we might be justified in privileging marginalized voices - a position with which I have sympathy). Then, too, we have silences present which, while they might reflect a harmonious spirit, might also reflect discomfort, a sense of being silenced, cultural differences towards silence, or a sense that real communication is not possible (Li, 2004). Jones understandably argues that dialogue is "based ... in a dominant group fantasy or romance about access to and unity with the other" (Jones, 2004, p. 63). Even when there are efforts to "un-marginalize the marginalized," significant social and cultural inequities existing at local and more global levels remain; local dialogues are not immune from their impacts. Then, too, we need to recognize, as Jones (2004) and Suzanne de Castell (2004) both do, that dialogue or its manifestations in hanging out will not necessarily resolve those inequities. Jones points to efforts designed at improving social conditions, suggesting that dialogue would be a "serendipitous by-product of [a] more oblique engagement" (p. 66). I would suggest, rather, that it would stand side-by-side as an integral part of comprehensive efforts designed to improve social conditions, in the spirit in which people like Paulo Freire (2006), and Peter McLaren (1995) imagined; it would both contribute to and emerge out of these other efforts.

Hanging out would embody what Gemma Corradi Fiumara (1990) calls a philosophy of listening, an attitude that "occupies no space but which in a paradoxical sense creates ever new spaces in the very 'place' it is carried out" (p. 19). Jones (2004) agrees, asserting that the work required of the dominant group thus becomes the work of listening. It is one which neither opposes an existing logos nor anything foreign to it, allowing what Alphonso Lingis (1994) calls a "community of those who have nothing in common" (p. 13). An absence of listening, of presence, and confirmation, of an inclusionary empathy, of a willingness to suspend one's certain hold on the nature of things can lead to oppression and the silences born of oppression and marginalization. The work of the dominants is not, as Freire (2006b) repeatedly reminds us, not to bring "liberation" to the marginalized, but to come and to allow others to the agora of dialogue where they and the marginalized can be transformed by their 
encounters. But Jones, like Freire, adds that those who are marginalized also have the work of presencing, voicing, and encounter. And for all the work carries on into daily lives. David Bohm once said, in response to people feeling discouraged that dialogue groups struggled so much, "I think people are not doing enough work on their own, apart from the dialogue groups" (as cited in Nicol, 2005, p. 17).

I would stress that, yes, there are times when encounters may be difficult and fraught with tension, when dialogue and the ethos of hanging out may be difficult if not impossible. The creation of safe spaces, the asking of true questions, the creative explorations, and "getting to deep" each do open up the possibility of conflict. If we "suffer together the destiny of our conditioned nature and meet one another in it," to use Buber's phrase, we open ourselves to the potential difficulties of difference. Isaacs' (1999) model of dialogical engagements outlines a four-stage process where conflict is a distinct, even likely, possibility as assumptions, expectations, and differences are surfaced. After initial periods of what he calls "politeness in the container" (which are often considered as genuine dialogues, but are usually just the beginning stage of dialogue $)^{13}$, people begin to open up and say what they really thinka "breakdown in the container," where superficial civility has been left behind. There are now three options: disengagement, retreat to polite civility where tensions are masked, or movements forward into genuine, if challenging, encounter when the container is strong enough to hold tension and opposition. Isaacs characterizes the movement forward as "inquiry in the field," where participants realize they do not have all the answers and are thrown back on their heels of unknowing, and where reflective and critical inquiry are possible and welcomed. The capacities I mentioned create, through their development and unfolding, the possibility of those encounters and the movement forward. The space created by hanging out can and indeed should remain open to critical engagement. Those engagements can be messy and even painful with no easy or possible solutions to tensions. There needs to be a recognition as well that others can, and, indeed, may have to, remain Other, unknowable and possibly even unfathomable, a sentiment echoed by Bernstein (1991), Lingis (1994), and Jim Garrison (2004,), who encourages risk-taking and the willingness to be vulnerable, adding that:

We must resist the notion we may ever know, recognize, or realize 'the other' with absolute certainty, nor can we complete the quest for certainty backwards by proving the other is unknowable, unrecognizable, or unrealizable. We must learn to live creatively with the paradox. (p.89)

This represents the significant challenge of diversity. As Jones concludes, educational settings may serve as one of the few places where such engagements can occur with some degree of safety, with some possibility of outcomes that are, while not necessarily easy or entirely satisfactory, meaningful and educational.

Suzanne de Castell (2004) asks, significantly, why we sanction dialogue as a pedagogical approach, suggesting that it does not have the positive effects presumed for it, and, further, that current conceptualizations of dialogue may not only prevent it from having the effects it might have, but in fact might contribute to serving as a means of marginalization. Her point is entirely valid, and I would suggest that conceptions of dialogue based on "the talking cure" or any form of conversation at all are not able to bear the burdens and expectations we place upon them and remain problematical. Dialogue is not a form of conversation, and to treat it as such means to lose touch with its foundations; we might as well just talk about talk, or worse, what Freire called "an alienated and alienating "blah"” (2006, p. 87). Dmitri Nikulin (2006) maintains that dialogue is often shallowly misconceived in ways which not only hinder its full development as praxis, but which also hinder our understanding of being-ness. Buber's philosophy of dialogue provides an ontological orientation to dialogue which, though it

${ }^{13}$ As Cris Mayo (2004, p. 35) puts it, civility becomes a practice which masks differences, not one which allows "discourse across difference." 
recognizes that dialogue certainly does occur through our speech acts, provides that ontological foundation from which these speech acts can be developed.

Briefly, dialogue is relationality, or perhaps a bit more precisely, an ethos of relationality. Although it manifests in and through signs and semiotic gestures, although it manifests in what Buber $(1947 / 2002)$ calls "men's traffic with one another" (p. 9), it is not limited to or defined by that traffic; it is what makes some of that traffic possible, but in essence it is not the traffic itself. Any acts of dialogue manifest through signs by virtue of its ontological foundations, our felt sense of relationality. As Buber points out (1947/2002), dialogue can exist without signs, but this is not obvious from a purely objective perspective; he goes so far as to say that dialogue reaches out beyond all the boundaries of any objectively observable forms of communication. Dialogue is a state of being, one which manifests itself in and through signs and semiotics, through the capacities which carry it; in that sense, it manifests as both being and the doings of the semiotic acts, whether these be speech acts, a tone of voice, a glance, a smile, a frown, an orientation of the body. Buber's philosophy of dialogue-more properly characterized as a life of dialogue ${ }^{14}$ — has its foundations in a relational ontology: the dialogical self. For Buber, the primary, ontological movement of dialogue was the "turning to the other" (Buber, 1947/2002, p. 25); when he says, in I and Thou (1958/2000), that "The Thou meets me. But I step into direct relation with it" (p. 26), the movement is an ontological one (although it may then manifest as a more outward form of action). He emphasizes that nothing, no sign or semiotic act, intervenes between $I$ and Thou; I and Thou represent "primary words" representing being, our ontological orientation to relationality, or what Buber (1947/2002) called the "sphere of between" (p. 241). Relationality represents the "essential attitude" of dialogue, allowing us to "flash up into presentness" (Buber, 1965b, p. 115) through the intersubjective encounter. He notes in Between Man and Man (Buber, 1947/2002) that the basic movements of dialogue - the turning toward the other in responsiveness — contributes to the establishment of that essential attitude. He notes, just as significantly, the "circle of essential action and essential attitude" (p. 25) which reciprocally establishes dialogue as doing and being-as praxisand which also establishes one's self and the Other and the wholeness of each.

Freire's $(2006 \mathrm{a} / \mathrm{b})$ formulations of dialogue are equally ontological in their foundations. The essence of dialogue, he asserts, lies in the word, but its constituents are a love of the world and life itself; dialogue founds itself in love, humility, and faith, and involves the ontological "vocation" of becoming more fully human. When he speaks of a "permanent relationship" of dialogue (2006b, p. 68), he makes it clear that he is speaking of an ongoing expression of consciousness, and he supports this claim by citing Alvaro Pinto, who writes of consciousness as the essence of a way towards something apart from itself; dialogue is for Freire a form of "consciousness intent upon the world" (p. 79). It's essence is relationality: "How can I dialogue if I regard myself as a case apart from others-mere 'its' in whom I cannot recognize other 'I's?" (p. 90). In his book Pedagogy of the Heart (2006a), Freire points to us being socioculturally and historically determined, mediated-by-the-world beings who are incomplete, unfinished; dialogue emerges out of life itself and the call of eros, the call "for more-life" (2006a, p. 92). Once again, we see human fulfillment in relation, and he characterizes education as the hopeful, searching efforts towards life and the world, a "conscious intending toward the world," and the "need for relational experience on the level of existence and of interactions, the level of living" (p. 94). He notes that even in solitude à sombra desta mangueria ("under the shade of this mango tree") he understands the "essentiality of to be with" (p. 29). To be sure, dialogue is for Freire action, but it is more than that; understanding its basis in praxis requires us to understand its ontological foundations. From these so much that is possible flows. Friere is adamant that dialogue cannot exist unless its participants engage in critical encounter, but he defines one of the elements of that critical encounter as the ability to see and

\footnotetext{
${ }^{14}$ Interestingly, in responding to his interlocutors late in his life, Buber replied: "I must philosophize; there is no other way to my goal, but my goal itself cannot be grasped philosophically" (in Rome \& Rome, 1964, p. 17). Of, course, that might depend on how one conceptualizes the practice of philosophy itself?
} 
to rest in the risky notion of reality as an unfolding process-and hanging out can serve as a dialogical response to unfolding realities.

\section{Dusking}

It began as a semi-formal dialogue in a room at the downtown campus. It was a spring evening, with the sun setting and long shadows growing outside the window. The quality of the light seemed to lend a quietening atmosphere, and the conversation just seemed gradually, imperceptibly to wind down. That conversation itself had been more or less just an informal one, just a group of people having an interesting dialogue, although it had had its serious and even its intense, agonistic moments, and there was plenty of diversity present in the room. As the pauses between people's words lengthened, we finally found ourselves just sitting together quietly in the gathering darkness. No one seemed to want to speak or move. No one seemed to feel uncomfortable. We all just sat there together. A satisfied silence. After about ten minutes, one person turned to her neighbour and quietly began talking. One by one, slowly, the rest of us stirred to talk and what emerged were groups of twos and threes: conversations once again coming alive. People just carried on talking about things that had arisen earlier, but now the conversations went deeper. Several people remarked that although they themselves were only engaged with one or two others, they felt connected to everyone in the room. As one person put it, "There was just a sense of a connecting presence in the room; we were all in our own ways talking about things that really mattered to us."

Almost three years later those who were present still remark on the power and beauty of that informal dusking session, and we came to name this the "dusking" phenomenon, referring to the occurrence of quiet, intimate, and profound conversations that go on and on and are symbolically characterized by the fading light of dusk - darkening, deepening. The informal nature of the dialogueone feature of which was silence-had allowed us to explore deeply meaningful subjects; out of this a powerful sense of both learning and community was generated. As Rilke (1997) writes, "Teaching means: to ask of each person / What he feels closest to in silence" (p. 135). But equally important were the rigors we had brought to our dialogical engagements; the practices of becoming aware, of being fully present, of confirming others, along with the other dialogical capacities, allowed us to ask effectively, meaningfully. It is of no small significance, I think, that most of those present brought with them intentional, committed, and sustained practice.

\section{Conclusion}

If hanging out has any value, it rests primarily in representing an effective opportunity to explore, create, and develop meaning and understanding, and to allow individuals to come into full presence, which are the goals of dialogue. While understanding may seem somewhat nebulous in a world devoted to concrete "results," understanding one another is a fundamental requirement in just about any shared venture. While, too, the value of full presence or being might seem questionable in an age of assessments, one might reasonably ask, as does Alfred North Whitehead (1967), what the aims of education are, and whether being or coming into being has anything to do with them. The question we have to ask is whether we are willing to devote the time and energy to a pedagogy of hanging out, and to creating the physical and psychic spaces necessary. In a world growing increasingly different, complex, and (dis-)connected, it makes sense to take the time to understand and to create the informal possibilities where such learning can occur.

As Gert Biesta (2004) argues, education takes place only in the "communicative interaction" of two or more people. It is, as he says, risky but it is also an opportunity, the only opportunity we really have: "it is the space ... where people_-individual, singular beings — can reveal who they are, can come 
'into presence"' (p. 22). Hanging out offers that opportunity. As mentioned, dialogue in all its forms takes time. Meanings and values, especially deeply-held ones-the foundation of so much-do not emerge in a minute. The irony of our lives is that death is ever-present, possibly in the next moment.

I began this essay by asserting that anyone can hang out. Of course, it is not quite that simple; for a number of reasons that may not always be possible. We have to discern whether we can and should create conditions where we and our students or colleagues can hang out together; it can't happen always, of course, and we have to decide whether its informality is appropriate to our goals and the needs of everyone involved. But there can be opportunities-even five minutes at the end of a class, or an hour with colleagues in an informal session, kicking around dreams and ideas, or an ad hoc session in which differences and grievances can rupture comfortableness-where hanging out can build a valuable sense of learning and community. Hanging out not only represents one of the high arts of dialogue, it also in many ways represents the essence of what dialogue embodies, that is, creating a safe space, respecting others' diversity, but at the same time being willing to ask and consider the true and possibly challenging questions. Dialogue also requires being comfortable with the flow of conversation into areas that might be new, foreign, and even unnerving, but at the same time creative, exciting, and beyond the confining walls of what was previously considered possible; risking vulnerability and coming into presence. Students are increasingly faced with the prospect of negotiating worlds that are ever more complex, connected, diverse, and uncertain. The informal, unstructured, emergent ethos of hanging out contribute to making it an appropriately responsive and powerful pedagogical practice, suited to exploring and navigating complexity, intersubjectivity, diversity, and uncertainty.

Educators can foster the practices and ethos of hanging out by creating the time and space (physical, by the choice of location, natural or within buildings, and in the latter the accompanying arrangement and types of furniture, lighting, and acoustics; and psychic, by demonstrating the qualities which facilitate hanging out, particularly in being present, open and receptive, respectful, and empathic); being present can require both spontaneity and the fruits of a committed, disciplined praxis. There needs to be a willingness to allow what Ted Aoki (2005) would call an emergent, "lived curriculum" (p. 203) where the road ahead is not clearly mapped out, where risks might be required and the unknown and the apophatic unknowable might be found, and where students are invited to participate in ways that are meaningful to them. As well, educators may have to consider the efforts required of themselves and others to "strengthen" the containers of dialogue so that they can hold the tensions of disagreement and difference. And, indeed, they will have to assess carefully whether students or employees have the willingness and the abilities to engage in what might involve significant risks.

Hanging out represents a dialogical response to unfolding realities, existential and emergentlayer upon layer, with life meeting life. It is undoubtedly a pedagogy of hope, proceeding from the possibilities of establishing trust out of a recognition of the concrete realities of ourselves and others, a pedagogy of hope which recognizes our "incompletion" (to use Freire's (2006b) word) and, just as significantly, our longings, urgings, and movements toward meeting, and the possibilities of completion within those meetings. There is, too, what Freire (2006b) referred to as the a priori requirement of an "intense faith in mankind" (p. 90); the dialogical person "believes in others even before he meets them" (p. 90-91). Freire's is, like Buber's, a recognition of the Romantic foundations of dialogue (especially in its ontological configurations); hanging out emerges out of and rests in that imaginative means of establishing that faith and of restoring that trust. Where Alison Jones asks us to reduce our romantic expectations of dialogue, I would suggest we improve our Romantic understandings of its ontological and imaginative foundations. As Maxine Greene (1995) states: "The role of imagination is not to resolve, not to point the way, not to improve. It is to awaken, to disclose the ordinary unseen, unheard, and unexpected" (p. 28). The practices of dialogue that hanging out entails represent what both Bernstein (1991) and Thayer-Bacon (2003) call an engaged fallibilistic pluralism (pp. 8, 70, 72) The dialogical encounter encapsulated in hanging out is uniquely capable of such a response. What is more, the development of that faith and the restoration of that trust come through its committed, rigorous practice. 


\section{Acknowledgments}

The author would like to thank the reviewers and Charles Bingham and Barb Kolbus for their very helpful comments and keen insights. For them: the comments are deeply appreciated.

\section{References}

Aoki, T. (2005). Curriculum in a new key: The collected works of Ted Aoki, W. Pinar \& R. Irwin (Eds.). Mahwah, NJ: L. Erlbaum Associates.

Banathy, B. \& Jenlink, P. (Eds.). (2005). Dialogue as a means of collective communication. New York: Kluwer Academic.

Bernstein, R. (1991). The new constellation: Ethical-political horizons of modernity/postmodemity. Cambridge, Mass.: MIT Press.

Biesta, G. (2004a). "Mind the gap!” In C. Bingham \& A. Sidorkin (Eds.), No education without relation (pp. 11-22). New York: Peter Lang.

Bingham, C. (2004). Let's treat authority relationally. In Bingham, C. and Sidorkin, A. (Eds.). No education without relation. N.Y.: Peter Lang.

Bingham, C. \& Sidorkin, A. (2004). No education without relation. N.Y.: Peter Lang.

Bohm, D. (1996). On dialogue. London: Routledge.

Boler, M. (Ed.) (2004). Democratic dialogue in education: troubling speech, disturbing silence. New York: Peter Lang.

Bringhurst, R. (2002). Poetry and thinking. In T. Lilburn (Ed.), Thinking and singing: Poetry and the practice of philosophy (pp. 159-172). Toronto: Cormorant Books.

Buber, M. (1947/2002). Between man and man. London: Routledge.

Buber, M. (1958/2000). I and thou. (R. Smith, Trans.). New York: Scribner.

Buber, M. (1965a). Elements of the interhuman. In M. Buber (M. Friedman, Ed.) The knowledge of man: $A$ philosophy of the interbuman (pp. 72-88). New York: Harper \& Row.

Buber, M. (1965b). The word that is spoken. In M. Buber (M. Friedman, Ed.)The knowledge of man: $A$ philosophy of the interbuman (pp. 110-120). New York: Harper \& Row.

Burbules, N. (1993). Dialogue in teaching: Theory and practice. New York: Teachers College Press.

Burbules, N. \& Rice, S. (1991). Dialogue across differences: Continuing the conversation. Harvard Educational Review, 61, 393-416.

Burbules, N. \& Rice, S. (1992). Communicative virtues and educational relations. Philosophy of Education Yearbook. Retrieved October 24, 2007 from: http://www.ed.uiuc.edu/EPS/PESYearbook/92_docs/rice burbules.HTM

Cohen, A. (2008). Becoming a Daoist educator. Paper presented at the annual conference of the Canadian Society for the Study of Education, June 1, 2008, Vancouver, BC.

Cohen, A. \& Heesoon Bai. Dao and Zen of teaching: Classroom as enlightenment field. Educational Insights, 11(3). Retrieved Nov. 15, 2008 from: http://www.ccfi.educ.ubc.ca/publication/insights/v11n03/articles/bai/bai.html.

Csikszentmihalyi, M. (1991). Flow: The psychology of optimal experience. N.Y.: HarperCollins.

Cummings, E. (1994). Complete poems, 1904-1962. In 20th century American poetry [electronic resource] Alexandria, WestVirginia: Chadwyck-Healey, Inc.

de Castell, S. (2004). No speech is free: Affirmative action and the politics of give and take. In M. Bolen, (Ed.), Democratic dialogue in education: troubling speech, disturbing silence (pp. 51-56). New York: Peter Lang.

Dictionary.com (no date). Retrieved on March 7, 2007 from http://dictionary.reference.com/search? $\mathrm{r}=2 \& \mathrm{q}=\mathrm{hang} \% 20$ out.

Doll, M. (1995). To the lighthouse and back: Writings on teaching and living. New York: Peter Lang Publishers. 
Doll, W. (2005). The culture of method. In W. Doll Jr., M. Fleener, D. Trueit, \& J. St. Julien (Eds.), Chaos, complexity, curriculum, and culture: A conversation (pp. 21-75). New York: Peter Lang.

Ellinor, L. \& Gerard, G. (1998). Dialogue: Rediscover the transforming power of conversation. N.Y.: John Wiley $\&$ Sons

Fiumara, G. (1990). The other side of language: A philosophy of listening. London: Routledge.

Freire, P. (2006a). Pedagogy of the heart. New York: Continuum.

Freire, P. (2006b). Pedagogy of the oppressed. New York: Continuum.

Gadamer, H. (2004). Truth and Method. New York.: Continuum.

Garrison, J. (2004). Ameliorating violence in dialogues across differences: The role of eros and logos. In M. Bolen, (Ed.), Democratic dialogue in education: troubling speech, disturbing silence (pp. 89-103). New York: Peter Lang.

Greene, M. (1995). Releasing the imagination: Essays on Education, the Arts, and Social Change. San Francisco: Jossey-Bass.

Griffin, S. (1995). The eros of everyday life: Essays on ecology, gender, and society. New York: Doubleday.

Habermas, J. (1979). Communication and the evolution of society. (T. McCarthy, Trans.). Boston: Beacon Press.

Heidegger, M. (1975). Early Greek thinking (D. Krell \& F. Capuzzi, Trans.). New York: Harper \& Row.

Hill P. (2004, October). The contexts of dialogue: Reflections on the power and limitations of dialogue. Paper presented at the biannual meeting of the National Coalition on Dialogue and Deliberation, Denver, CO.

Hwoshinsky, C. (2002). Listening with the heart: A guide for compassionate listening. Indianola, WA: The Compassionate Listening Project.

Isaacs, W. (1999). Dialogue and the art of thinking together. N.Y.: Doubleday.

Jenlink, P. \& Banathy, B. (2008). Dialogue as a collective means of design conversation. New York: Springer.

Jones, A. (2004). Talking cure: The desire for dialogue. In M. Boler (Ed.), Democratic dialogue in education: troubling speech, disturbing silence (pp. 57-67). New York: Peter Lang.

Laverty, M. (2007). Dialogue as philosophical inquiry in the teaching of tolerance and sympathy. Learning Inquiry, 1(2), 125-132.

Li, H. (2004). Rethinking silencing silences. In M. Boler (Ed.), Democratic dialogue in education: troubling speech, disturbing silence (pp. 69-86). New York: Peter Lang.

Lilburn, T. (1999). Living in the world as if it were home. Toronto: Cormorant Books.

Lingis, A. (1994). The community of those who have nothing in common. Bloomington IN: Indiana University.

Lorde, A. (2007). The uses of the erotic: The erotic as power. In K. Lovass \& K. Jenkins (Eds.), Sexualities \& communication in everyday life: $A$ reader (pp. 87-94). Thousand Oaks, CA: Sage Publications.

Mayo, C. (2004). The tolerance that dare not speak its name. In M. Boler (Ed.), Democratic dialogue in education: troubling speech, disturbing silence (pp. 33-47). New York: Peter Lang.

McLaren, P. (1995) Critical pedagogy and predatory culture. London: Routledge.

Merriam-Webster Online (no date). Retrieved March 7, 2007 from http://www.mw.com/dictionary/hang+around.

Nicol, L. (2005). Wholeness re-gained: Revisiting Bohm's dialogue. In B. Banathy \& P. Jenlink (Eds.), Dialogue as a means of collective communication (pp. 17-28). New York: Kluwer Academic.

Nikulin, D. (2006). On dialogue. Lanham, MD: Rowman \& Littlefield Publishing Group.

Reeder, S. (2005). Classroom dynamics and emergent curriculum. In W. Doll Jr., M. Fleener, D. Trueit, \& J. St. Julien (Eds.), Chaos, complexity, curriculum, and culture: A conversation (pp. 247-260). New York: Peter Lang.

Rilke, R. (1997). Diaries of a young poet. N.Y.: W.W. Norton \& Company.

Rome, S. \& Rome, B. (Eds.). (1964). Philosophical interrogations: Interrogations of Martin Buber, John Wild, Jean Wabl, Brand Blanshard, Paul Weiss, Charles Hartshorne, Paul Tillich. New York: Holt, Rinehart, and Winston. 
Barks, C., Moyne, J., \& Rumi, J. (1997). The essential Rumi (C. Barks \& J. Moyne, Transl.). Edison, NJ: Castle Books.

Sallis, J. (1986). Being and logos: The way of Platonic dialogue. Atlantic Highlands, NJ: Humanities Press International.

Scharmer, C. O. (2007). Theory U: Leading from the future as it emerges- the social technology of presencing. Cambridge, MA: Society for Organizational Learning.

Senge, P. (2006). The fifth discipline: The art and practice of the learning organization (2nd ed.). New York: Currency Books.

Snowber (Schroeder) C. (1999). The eros of listening: Dancing into presence. Journal of Curriculum Theorizing, 15(3), 17-25.

Snowber, C. (2005). The eros of teaching. In J. Miller, S. Karsten, D. Denton, D. Orr \& I. C. Kates, (Eds.), Holistic learning: Breaking new ground. New York: State University of New York Press.

Stengel, B. (2004). Knowing is response-able relation. In Bingham, C. \& Sidorkin, A. (Eds.), No education without relation. NewYork: Peter Lang.

Thayer-Bacon, B. (2003). Relational (e)pistemologies. New York: Peter Lang.

Trueit, D. (2005). Watercourses: From poetic to poietic. In W. Doll Jr., M. Fleener, D. Trueit, \& J. St. Julien (Eds.), Chaos, complexity, curriculum, and culture: A conversation (pp. 77-99). New York: Peter Lang.

Whitehead, A. (1967). The aims of education. In The aims of education and other essays (pp. 1-14). New York: The Free Press.

Wilber, K. (2001). Sex, ecology, and spirituality, 2nd ed. Boston: Shambhala.

Winnicott, D. (1971). Playing and reality. London: Routledge.

Yankelovich, D. (1999). The magic of Dialogue. N.Y.: Simon \& Schuster.

Yankelovich D. (2004). On taking leadership for building trust. Lecture given at Simon Fraser University, sponsored by the Morris J.Wosk Centre for Dialogue, Nov. 10, 2004, Vancouver, BC.

Yunchuan, D. (1996). Lao Zi's thought and contemporary Chinese educational thought. In R. Hayhoe \& J. Pan (Eds.), East-West dialogue in knowledge and higher education. Armonk, NY: M.E. Sharpe.

\section{About the Author}

Charles Scott is a doctoral candidate in the Arts Education program at Simon Fraser University who messes around with the various uses and methodologies of dialogue in educational settings; he hangs out, not always successfully, on both sides of the track-and sometimes manages to remain in the space between. 